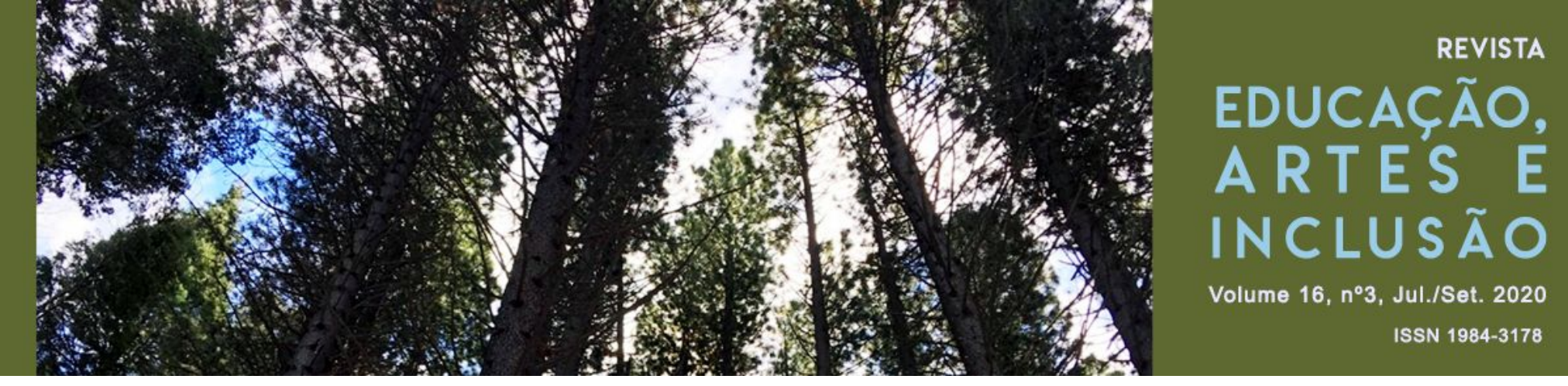

\title{
APRENDIZES DE SI: PERCURSOS PARA SENTIR/PENSAR AS ARTES E AS CULTURAS SILENCIADAS
}

\section{SELF APPRENTICESHIP: PATHS TO FEEL / THINK THE SILENCED ARTS AND CULTURES}

\author{
DOI: http://dx.doi.org/10.5965/198431781632020147 \\ Teodora de Araújo Alves \\ Universidade Federal do Rio Grande do Norte \\ teodora.alves@gmail.com | ORCID
}

\section{RESUMO}

A formação universitária pode possibilitar caminhos menos coloniais de ensino e aprendizagem, desde que a natureza plural da sua própria comunidade seja reconhecidamente considerada em seus processos formativos e nas tomadas de decisões institucionais, sendo, desse modo, uma instituição educativa que não se enclausure no colonialismo separatista, discriminatório, distanciador dos sujeitos que dela fazem parte. $O$ corpo, por vezes, negado/oprimido em função da sua cor; da sua nacionalidade; da sua "classe social", da sua cultura, resiste pela afirmação daquilo que coletivamente foi instituído como sendo sua identidade; seus processos identitários, sua africanidade. Nesse contexto, a arte, pode se tornar um elemento agregador do processo de luta e afirmação. Este estudo fenomenológico, portanto, tem como objetivo enfatizar a força das africanidades, do corpo e de algumas expressões artísticas afro-brasileiras como práticas decoloniais possíveis de ser trabalhadas no ensino superior. A metodologia adotada foi uma pesquisa bibliográfica bem como uma exposição do acervo da autora a fim de apresentar experiências com as africanidades. Como resultado, aponta que docentes tomem também para si a responsabilidade de repensar suas práticas acadêmicas a partir da diversidade e das idiossincrasias dos sujeitos que a integram, na perspectiva de contribuírem para a constituição de uma universidade pluriversitária.

Palavras-chaves: Formação universitária; Práticas decoloniais; Expressões artísticas; Corpo. Africanidades.

\section{ABSTRACT}

University education can enable fewer colonial methods of teaching and learning, since the plural nature of the university's own community be recognized in its formative processes and institutional decision-making, being, in this way, an educative institution that is not cloistered in separatist colonialism; that is not discriminatory; that is not creating distance from the subjects that are part of it. The body, sometimes, denied/oppressed because of its color; its nationality; its "social class"; its culture resists by affirming what was collectively instituted as its identity; its identity processes; its Africanness. In this context, art can become an aggregating element in this process of struggle and affirmation. This phenomenological study, hence, aims to emphasize the power of Africaness, body and some Afro-Brazilian artistic expressions as references for decolonial practices that can be discussed in the higher 


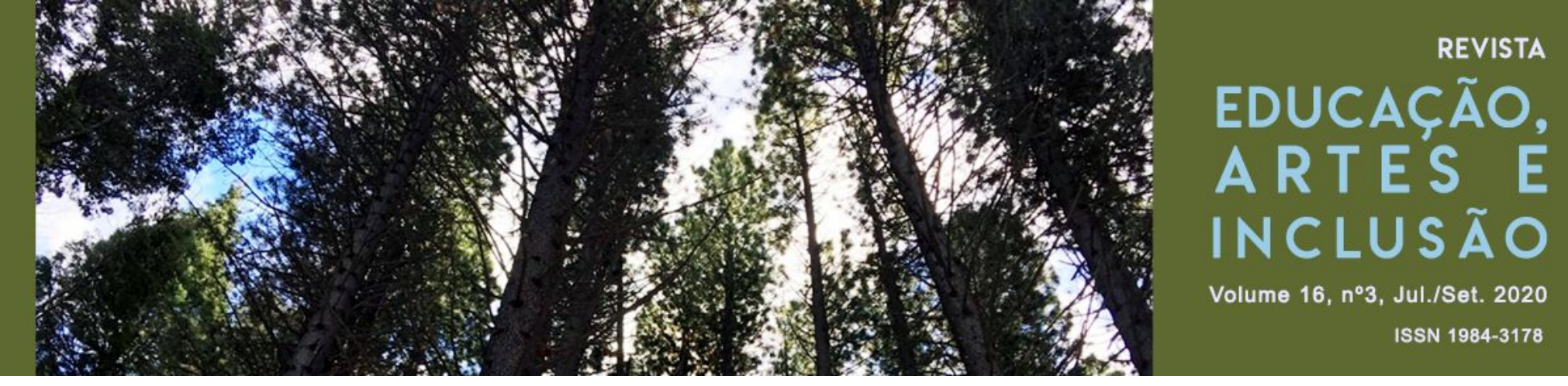

que se cruzam e dialogam entre si. Entendemos que essa é a riqueza da educação. $\mathrm{Na}$ vida real, estão a diversidade, a multiplicidade, a pluralidade de saberes e fazeres dos sujeitos. Transitar nessas realidades pode nos permitir enxergar determinados aspectos que nem sempre conseguimos mostrar aos nossos estudantes quando focamos apenas no ambiente universitário. Vivenciar outros contextos que não apenas o da sala de aula convencional pode nos conduzir a outros olhares, a muitas outras vozes, por vezes, silenciadas; a perceber diferentes situações, saberes e fazeres, corpos-sujeitos com suas virtudes e suas problemáticas. Dar voz ao outro, percebê-lo e não o negligenciar é assumir uma atitude dialógica da qual tanto a educação necessita.

Infelizmente, o que temos visto é que recorrentemente os processos epistemológicos são tragados pela descontextualização das realidades culturais e políticas, como ressaltam Boaventura Santos e Maria Paula Meneses (2010). Nesse sentido, podemos pensar sobre culturas silenciadas, aquelas que comumente não fazem parte dos processos educativos institucionalizados. Quando muito, essas instituições formativas consideram os diferentes saberes como objetos a ser estudados, explorados, a partir de um olhar eurocêntrico, epistêmico, do norte sobre o sul, como reforçam os autores supracitados (SANTOS; MENESES, 2010).

Ser professor(a) e ser estudante deveria realmente significar tornarmo-nos aprendizes de nós mesmos. Conscientes dessa condição, talvez conseguíssemos pensar mais sobre nossa participação nos processos de construção do conhecimento e sobre nossa condição existencial de sujeitos culturais, sociais e políticos, permitindo-nos, assim, enxergar as ausências-presenças de nós mesmos nesses processos.

Nessa perspectiva, a educação institucionalizada não seria tratada como um campo apartado do mundo-vivido pelos próprios sujeitos da ação educativa, com seus modos de ser, agir e pensar. Quando estamos imersos em contextos excludentes, é necessária uma aprendizagem de desaprender, para que 


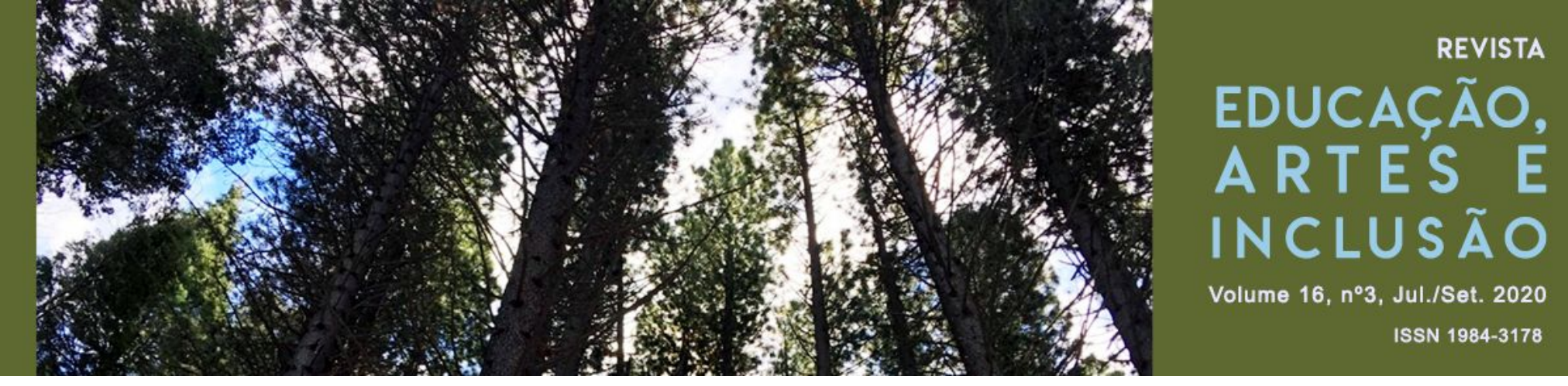

consigamos adotar outros modos decoloniais de ensinar e aprender. Sobre decolonialidade, nós tomamos como referência os pensamentos do Grupo Modernidade/Colonialidade (M/C), constituído no final dos anos 1990 e formado por intelectuais latino-americanos, a exemplo do filósofo argentino, Enrique Dussel; do sociólogo peruano, Aníbal Quijano; do semiólogo e teórico cultural argentino-norte-americano, Walter Mignolo, entre outros.

Como nos disse Walter Mignolo, o fato de os gregos terem inventado o pensamento filosófico, não quer dizer que tenham inventado 0 Pensamento. O pensamento está em todos os lugares onde os diferentes povos e suas culturas se desenvolveram e, assim, são múltiplas as epistemes com seus muitos mundos de vida. Há, assim, uma diversidade epistêmica que comporta todo o patrimônio da humanidade acerca da vida, das águas, da terra, do fogo, do ar, dos homens (PORTO-GONÇALVES, 2005, p. 9).

Quebrar as colonialidades significa, entre outras ações, considerar outros modos de ser e de viver, outras perspectivas, sobretudo daqueles que foram colocados à margem pela dominação epistêmica eurocêntrica.

A colonialidade nomeia a lógica subjacente da fundação e do desdobramento da civilização ocidental desde o Renascimento até hoje - da qual, colonialismos históricos têm sido uma dimensão constituinte, embora minimizada. O conceito como empregado aqui, e pelo coletivo modernidade/colonialidade, não pretende ser um conceito totalitário, mas um conceito que especifica um projeto particular: o da ideia da modernidade e do seu lado constitutivo e mais escuro, a colonialidade, que surgiu com a história das invasões europeias de Abya Yala, Tawantinsuyu e Anahuac, com a formação das Américas e do Caribe e o tráfico maciço de africanos escravizados (MIGNOLO, 2017, p. 2).

A formação universitária pode nos possibilitar caminhos menos coloniais de ensinar e aprender, desde que a natureza plural da sua própria comunidade seja reconhecidamente considerada em seus processos formativos e nas tomadas de decisões institucionais, sendo, desse modo, uma instituição que não se enclausure 


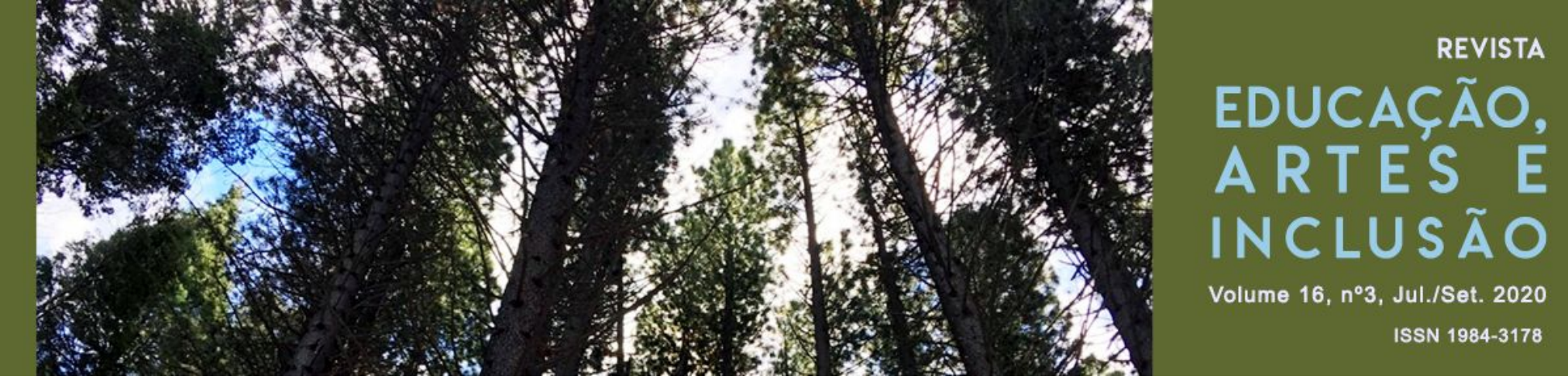

no colonialismo separatista, discriminatório, distanciador dos sujeitos que dela fazem parte. Aprendizes de si, título do nosso texto, é o exercício diário para seguirmos na direção da conscientização e da defesa das vozes historicamente silenciadas. Nessa perspectiva, portanto, apresentamos alguns dos resultados obtidos a partir de experiências artísticas decoloniais vividas no contexto universitário.

\section{VOZES ANCESTRAIS: A ÁFRICA ESTÁ EM NÓS}

O quanto me foi importante pisar o chão africano e sentir-me nele como quem voltava e não como quem chegava (FREIRE, 1978, p. 14).

Iniciamos este tópico com essa epígrafe de Paulo Freire, ao registrar sua primeira experiência na África. Nós a tomamos como inspiração para refletirmos sobre nosso chão brasileiro, nosso chão nordestino, nosso chão universitário, pensando sobre o quanto é necessário percebermos esses territórios como espaços construídos por muitos corpos-sujeitos, que - apesar de tanto suor e lágrima postos no processo de construção deste país nesses 520 anos de história - continuam consideravelmente com suas vozes silenciadas pelas forças colonizadoras. A África está em nós, latente, pulsante, potente e o que, entre outras necessidades, precisamos é de reconhecer, enxergar, oportunizar que os seus conhecimentos, suas práticas de saberes, integrem perenemente nossos currículos, nossas ações metodológicas, nossos olhares e intervenções educacionais. Continuamos, então, com Freire, ao nos brindar com o seu memorável relato ao pisar pela primeira vez no continente africano:

[...] atravessava a cidade, ela ia se desdobrando ante mim como algo que eu revia e em que me reencontrava. Daquele momento em diante, as mais mínimas coisas - velhas conhecidas - começaram a falar a mim, de mim. A cor do céu, o verde-azul do mar, os coqueiros, as mangueiras, os cajueiros, o perfume das flores, o cheiro da terra, as bananas, entre elas a minha bem amada banana-maçã; o peixe 


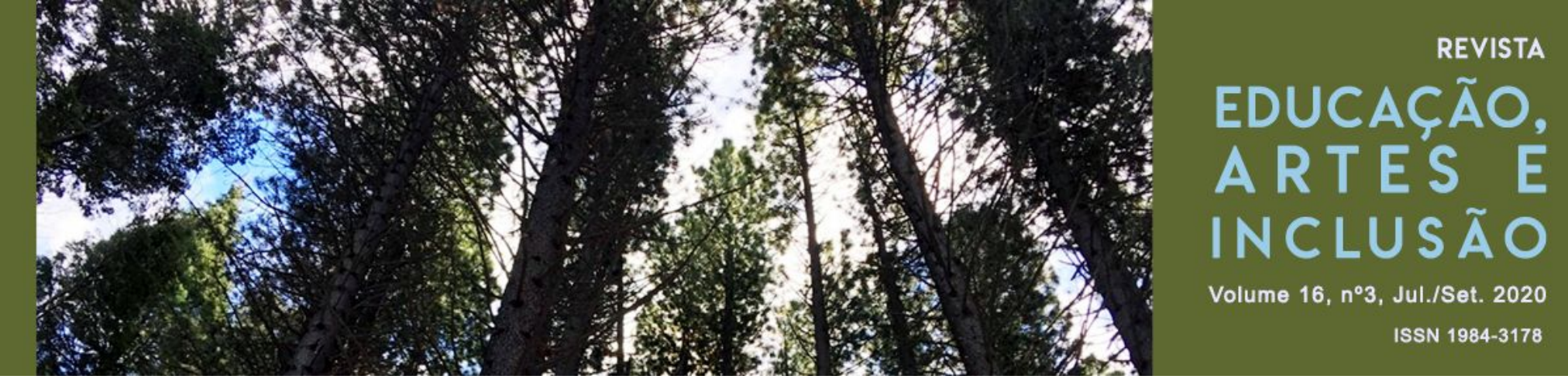

ao leite de coco; os gafanhotos pulando na grama rasteira; o gingar do corpo das gentes andando nas ruas, seu sorriso disponível à vida; os tambores soando no fundo da noite; os corpos bailando e, ao fazê-lo, "desenhando o mundo", a presença, entre as massas populares, da expressão de sua cultura que os colonizadores não conseguiram matar, por mais que se esforçassem para fazê-lo, tudo isso me tomou todo e me fez perceber que eu era mais africano do que pensava. [...] Aquele encontro que era um reencontro comigo mesmo (FREIRE, 1978, p. 13-14).

Nessa perspectiva, há tantas outras expressões que comprovam o quanto a África está em nós e o quanto temos de mulheres e homens negros responsáveis por grandes realizações brasileiras, de forma que:

Não é possível pensar o Brasil sem o barroco nas mãos de Antônio Francisco Lisboa, o Aleijadinho. Sem a medicina psiquiátrica de Juliano Moreira, sem a poesia e os processos jurídicos de Luiz Gama, sem os romances de Machado de Assis, sem as pinturas dos irmãos Timótheo, sem as estradas, as doces e edificações de André e Antônio Rebouças, sem o serviço de urbanização de Teodoro Sampaio, sem a concepção geopolítica de Milton Santos. E sem a participação de muitos e muitos outros importantes homens e mulheres da ciência, da politica, da religião e das artes (MUSEU AFRO BRASIL, 2015).

Como professores, estudantes e sociedade, importa-nos indagar sobre de que maneira a África está em nós; no nosso cotidiano e nas nossas ações e não apenas considerarmos referências negras em momentos sazonais ou comumente tê-la como um continente distante de nossa realidade brasileira ou vinculada ao período escravocrata. O corpo, o espaço e o tempo precisam ser relativizados, questionados, problematizados para que percebamos os corpos-sujeitos que somos e com os quais convivemos; os espaços outros que vão além de uma sala de aula quadrada e inerte; e o tempo presente, tanto vinculado a questões do passado quanto a questões que dizem respeito ao nosso futuro. Nesses termos, é preciso perceber o corpo como fonte de sentidos, que experiencia fenomenologicamente a si 


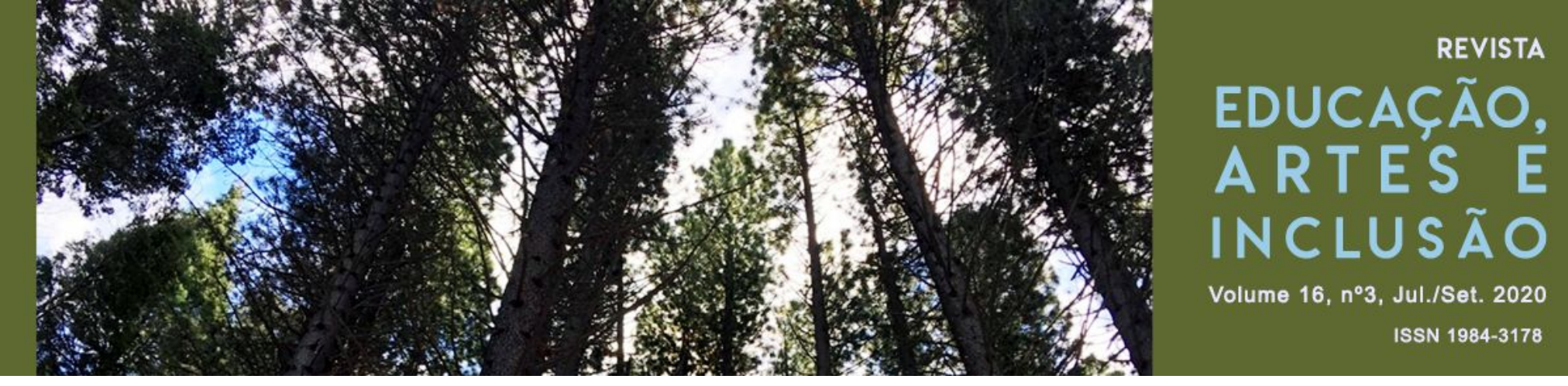

mesmo e o mundo, como nos diz Merleau-Ponty (1999). Nesse caso, temos as africanidades como vozes potentes de resistência frente ao histórico silenciamento dos corpos negros. É sobre isso que também falaremos a seguir.

O termo africanidades, na perspectiva do antropólogo e professor congolês, Kabenguele Munanga (1998), diz respeito a traços comuns ao mesmo modo de pensar e de viver de grupos que habitam basicamente na região ao sul do Saara, ou subsaariana. Alguns desses traços são: a relação de parentesco; o poder do cântico e da dança; e a crença na ancestralidade. Para o referido antropólogo, em uma de suas entrevistas,

Africanidades não é nada mais que a resistência da cultura africana. Toda a cultura africana, que foi reprimida aqui, resistiu. Contribuiu na formação da identidade brasileira. No modelo de comportamento brasileiro. Essa africanidade está na cultura, e está na própria língua portuguesa falada no Brasil, que recebeu influência muito grande. Essa africanidade, que está na religião, que está na cultura, que está no nosso próprio corpo, que está nos esportes - como a capoeira e tantos outros -, que está nas artes plásticas, esses são os valores africanos. E nosso gesto, e nosso movimento (MUNANGA, 2008. Entrevista Salto para o Futuro/TV Escola).

A África subsaariana é um grande mosaico constituído de diversos povos do planeta.

São mais de mil etnias. Sob essa variedade de culturas e formas, a arte africana esconde sempre uma dimensão religiosa e cultural a descobrir. [...] a arte africana pode despertar surpresa, encantamento ou mesmo espanto, mas nunca indiferença (CATEL; SAVINO, 2012, p. 9).

Cabe ressaltar que, segundo Querino (1988), o uso frequente do termo África, sem especificar qual região, quais etnias ou grupos culturais, leva-nos ao equívoco de uma visão totalizadora e homogênea de um continente múltiplo e altamente diferenciado. Nesses termos, é preciso atentar "para não incorrer na postura racista 


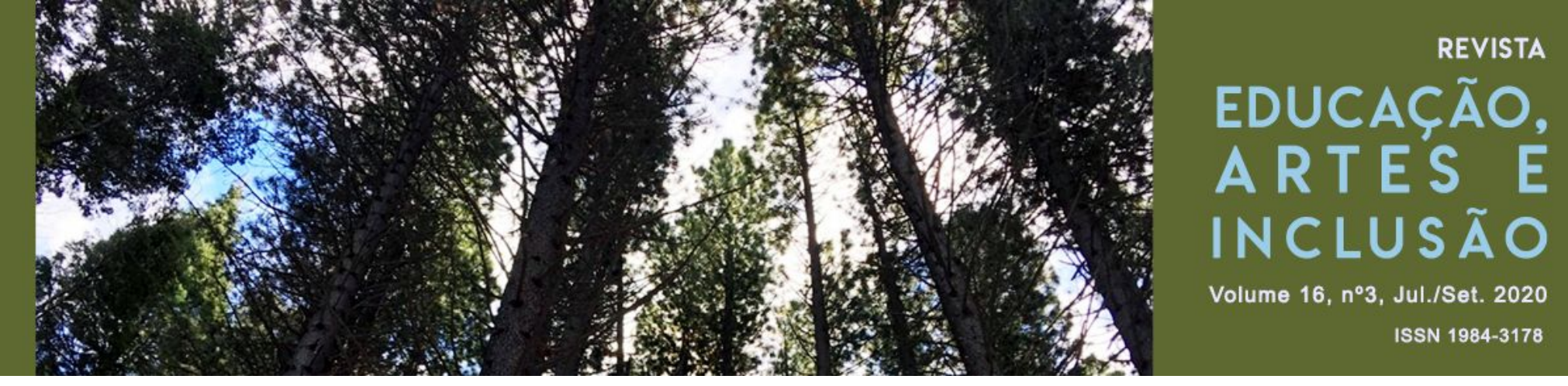

de dividir a África numa branca e outra negra, optou-se por falar de uma África do norte, e de outra ao sul do Saara" (QUERINO, 1988, p. 90).

No Ocidente, fomos educados prioritariamente pelo pensamento moderno que nos conduziu muitas vezes a enxergar o mundo linearmente, pelo prisma da razão cartesiana; negando o corpo, o sensível e nos levando a privilegiar uma única forma de conhecer o mundo, ou seja, a forma da ciência positivista, do racional, do já instituído e do testado e comprovado. Em contraponto a essa visão dualista, partimos da abordagem fenomenológica da percepção que nos permite, com o filósofo Merleau-Ponty (1999), compreender o sujeito a partir de sua materialidade corpórea-existencial-perceptiva, isto é, o sujeito da experiência é o mesmo que percebe e produz conhecimento, e esse não é um ser de uma essência desencarnada e apartada do mundo. Nas palavras do filósofo,

[...] não é o sujeito epistemológico que efetua a síntese, é o corpo; quando sai de sua dispersão, se ordena, se dirige por todos os meios para um termo único de seu movimento, e quando, pelo fenômeno da sinergia, uma intenção única se concebe nele (MERLEAU-PONTY, 1999, p. 312).

Norteado por pressupostos dessa natureza, o presente texto parte da perspectiva fenomenológica de entendimento do corpo como condição primeira e irrevogável da existência humana e da sua capacidade perceptiva e expressiva no mundo vivido. Corpo, percepção e expressão integram a condição existencial do ser e estar no mundo como humanos, biologicamente falando e como produtores de cultura. Percepção, sob esse viés, é entendida como experiência do corpo, pois a apreensão das significações se faz pelo corpo: "aprender a ver as coisas é adquirir um certo estilo de visão, um novo uso do corpo próprio" (MERLEAU-PONTY, 1999, p. 212).

Nesse sentido, o antropólogo francês David Le Breton também nos permite refletir sobre a concepção de corpo como sendo a própria condição humana da 


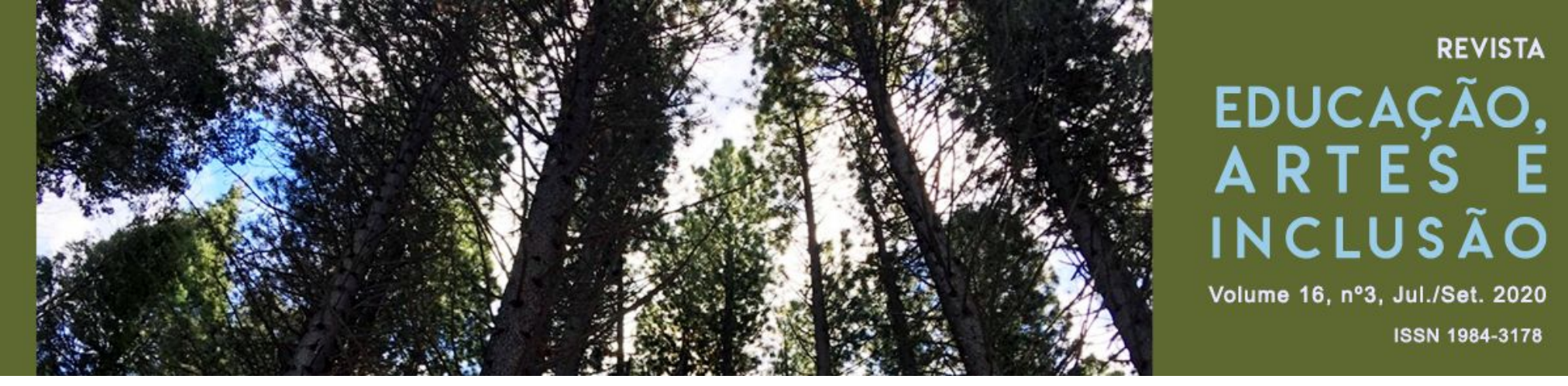

existência, ao afirmar, em uma de suas entrevistas, que a condição humana é corporal. O corpo não é somente um suporte, ele é a raiz identificadora da vida humana, o condutor de toda a relação com o mundo (LE BRETON, 2008).

Nas culturas africanas, há outros modos de existir, de enxergar o mundo; de percebê-lo. Especificamente no contexto subsaariano, o mundo-vivido confunde-se com a própria condição corporal de percebê-lo, afinal, o corpo que percebe é o mesmo que é exaltado por seus modos de existir, de ser e fazer, de pensar, de sentir e de agir. Trata-se de um lugar onde o corpo parece situar-se a partir de sua inteireza de ser corpo-sujeito, com suas diversas maneiras de ser e estar no mundo. Nesse processo, encontramos um corpo que pensa, cria, expressa, age, interage; o corpo-vivo-pulsante. Esse é o corpo-artístico-cotidiano; o corpo nitidamente cultural, vibrante, resistente; que cria sua arte a partir do vivido, ou melhor, confunde-se com ele próprio, e, portanto, com seus traços de africanidades. Reafirmando tal reflexão, temos o pensamento de Catel e Savino (2012, p. 8), quando entende que "os povos africanos têm uma concepção sobre arte muito distinta daquela a que estamos acostumados a ver e aprender no chamado mundo ocidental". Afinal, como nos bem lembra Boff (2000),

Ser negro é uma forma singular de estar-no-mundo. Na verdade, dever-se-ia falar no plural, das várias culturas negras, porque recobrem várias nações, com línguas, tradições, metafísicas e religiões diferentes. Mas elas têm isso em comum: não são culturas ocidentais. Trabalham outro tipo de racionalidade, outra relação com o corpo, outras emoções, elaboram diferentemente o imaginário, a compreensão da vida, da morte e a relação com os ancestrais (BOFF, 2000, p. 126).

O corpo, para os povos africanos, traduz-se em ponto de conexão entre a natureza e a cultura, entre a existência terrena e a espiritual, entre o visível e o invisível. No que tange às expressões de artes africanas na região subsaariana, temos uma imensa variedade de artefatos, danças, músicas, cânticos que se 


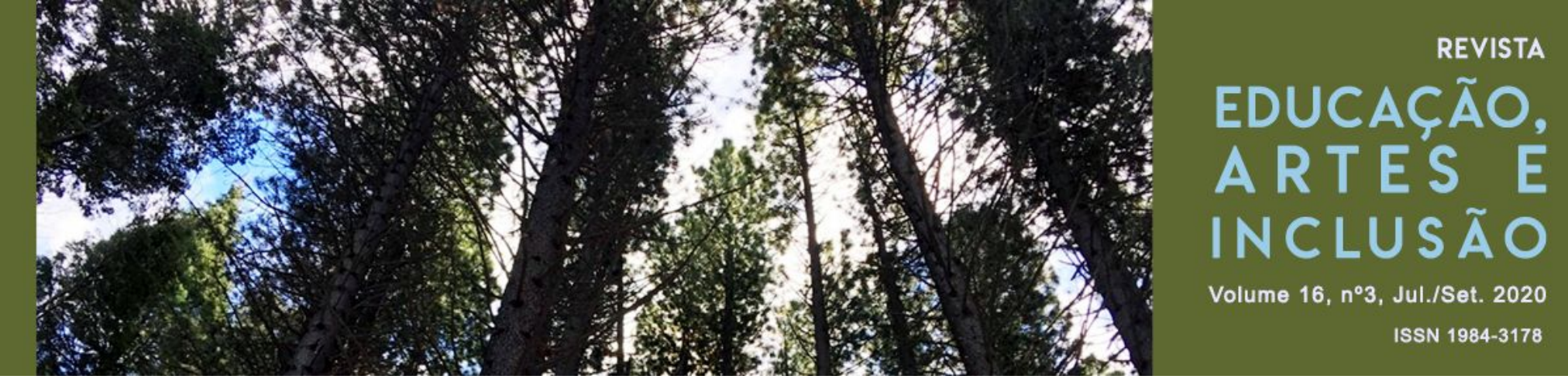

traduzem em expressões sociais e culturais, advindas desses universos étnicos, simbólicos, corpóreos.

$\mathrm{Na}$ concepção de Léopoldo Senghor, escritor e filósofo senegalês, "[...] a chama não se extinguiu, a semente está ainda em nossos corpos e corações feridos, para possibilitar nosso renascimento hoje" (SENGHOR, 1968, p. 191). Para esse autor, o homem negro traz em si e em suas reflexões, em suas ações culturais e interações sociais, o “ato de conhecimento como um 'acordo de conciliação' com o mundo, a consciência simultânea e a criação do mundo em sua unidade indivisível" (SENGHOR, 1968, p. 207). Nesses termos, sua arte coaduna-se com esses estados de ser e estar cultural e socialmente se conectando com o mundo vivido, com a natureza, com sua própria condição de ser simbólico e espiritual. Nesse contexto, é possível encontrar comunidades em festas, em estado de resistência por meio de sua arte, expressando aspectos de sua etnicidade, de sua história ancestral, de suas árduas lutas por cidadania e respeito.

Na coleção A Cor da Cultura, encontramos uma reflexão a esse respeito, isto é: "Os deuses dançam e celebram a vida. Assim também fazem os que neles acreditam. As festas em grupo, o som do tambor, os movimentos da dança podem ser instrumento de oração e reverência às forças espirituais" (BRANDÃO, 2006, p. $52)$.

Nossas memórias saltam aos olhos e rapidamente lembramos o Zambê, dança de coco típica das redondezas do Rio Grande do Norte, encontrada no município de Tibau do Sul (ALVES, 2006). A esse respeito, citamos uma fala de Mário de Andrade, por ocasião de sua visita às terras cascudianas, no ano de 1928:

De longe se escuta um zambê noutra casa de empregados. O som do bumbo "zambê" se escuta de longe. Vamos lá. O pessoal dança passos dificílimos. O tambor bate soturno em ritmo estupendo. Estou no meu quarto e inda o zambê rufa no longe. Adormecerei e ele ficará rufando (ANDRADE, 2015, p. 233). 


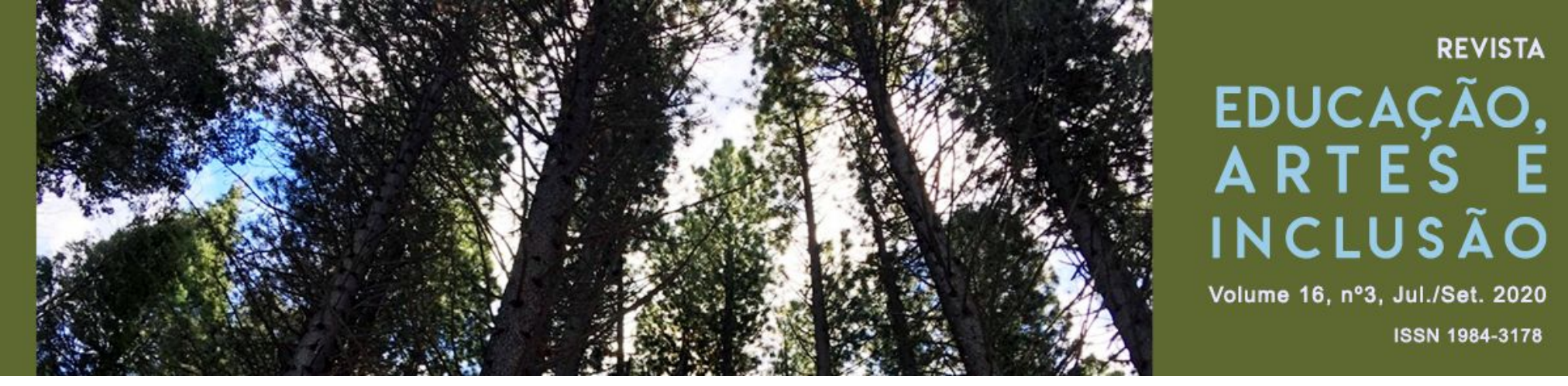

No ato da dança do Zambê, existe um respeito mútuo entre os brincantes. Cada um tem seu momento de saudar o instrumento maior, de brincar no centro da roda, de ir até o companheiro e realizar a umbigada. Todavia, mesmo quem não esteja no centro da brincadeira, fica sendo um integrante do círculo e, com movimentos mais sutis de batidas de pés e mãos, dançam e cantam para quem se encontra dentro da roda. Afinal, o que está em jogo é tanto o brilho individual como o esplendor coletivo (ALVES, 2000).

Nesse contexto artístico-vivencial, a dança mostra-se reveladora de gestualidades, oralidades e corporeidades próprias dos corpos negros que dançam para "honrar o seu lugar", reverenciar a sua história ancestral - repetimos, então, a frase dita por um querido mestre popular da dança dos Congos, executada na Vila de Ponta Negra em Natal/RN, nós nos referimos ao Mestre José Correia (in memoriam), quando disse muitas vezes: "Eu brinco pra honrar o meu lugar" (ALVES, 2010, p. 133). Ele era um homem negro, de uma força exemplar, de um amor e de um sentimento de pertencimento forte à sua cultura e à sua ancestralidade herdada de sua família brincante de Congos.

Evidentemente, não podemos negar o que as artes africanas - ou aquelas presentes em outras nações a partir da diáspora africana - suscitam em termos de conteúdo, de reverência à história étnica de quem as produz, mas também devemos ressaltar as condições subumanas pelas quais passaram as pessoas negras. Sobre isso, Nelson Inocêncio, professor da Universidade de Brasília, ao citar Hans Belting, diz o seguinte:

Concordo com Belting quando, ao afirmar o fim da história da arte, sugere que uma história da arte contemporânea verdadeiramente comprometida com as questões do seu tempo terá que levar em conta não apenas a produção de artistas oriundos de países não hegemônicos, mas também aquilo que o conteúdo de suas obras suscita. Se o futuro próximo puder contemplar as alteridades de forma efetiva e afetiva teremos a chance de pensar e escrever a história da cultura e da história da arte sobre novas bases (INOCÊNCIO, 2011, p. 189). 


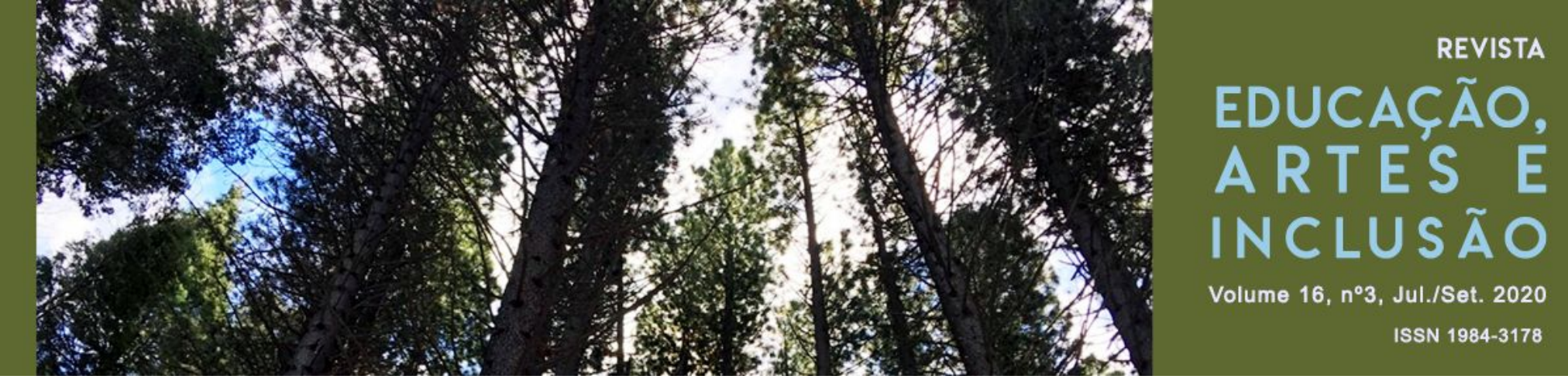

um modo geral, da sociedade, para perceber essa diversidade de referências culturais, artísticas e estéticas presente no contexto da arte brasileira. Estará, de fato, sensível nosso olhar a ponto de nos permitir enxergar para além das referências eurocêntricas, inclusive no campo da arte? Nessa perspectiva, fica o convite para nos sensibilizarmos de corpo inteiro e vivermos a experiência estética com as várias possibilidades de expressão da arte de matrizes africanas.

\section{FRUIÇÃO ESTÉTICA: VISIBILIDADES DA ARTE AFRICANA}

A integração de alguém ao universo de dada cultura exige-lhe vontade de participar dela (COSTELLA, 1997, p.12)

Nesse contexto refletivo e propositivo sobre a evidência de vozes silenciadas e a necessidade de uma educação institucional efetivamente plural, apresentamos, neste tópico, imagens de obras artísticas tematizando africanidades e questões de natureza estética, a fim de percebermos o quão rico é trabalhar com outras possibilidades para além de uma educação e uma história da arte eurocêntricas. Nesse sentido, Costella, ao falar sobre apreciação artística, afirma que:

A obra de arte, como entidade física, é inteira e única. No entanto, na mente do espectador podem ser selecionados diferentes ângulos de observação. Essa diversidade, de angulação mental, quando inteiramente realizada, permitirá ao observador ver a obra de arte em toda a sua riqueza, absorvendo de modo completo o respectivo conteúdo (COSTELLA, 1997, p. 12).

No processo de ensino e aprendizagem com a arte, almeja-se que o educador assuma a figura de um mediador e promova trocas de pontos de vista entre os espectadores, acrescidos de outros trazidos por teóricos e estudiosos, rompendo os preconceitos estereotipados, ampliando conhecimentos e gerando novas problematizações (MARTINS; PICOSQUE, 2012). Nesse contexto, referimo-nos não 


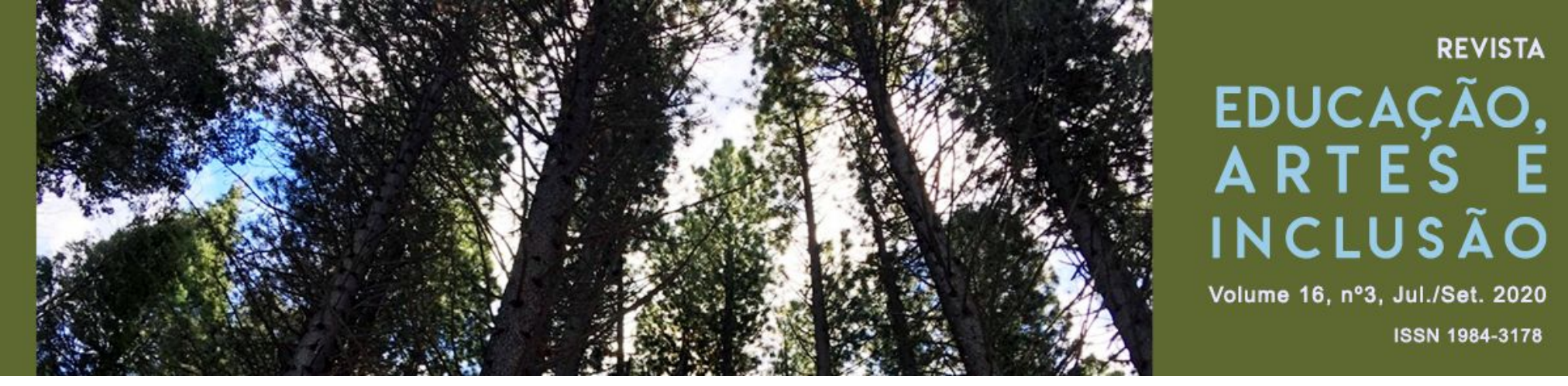

hierarquizações, críticas a respeito da obra; a comercial refere-se ao seu valor artístico, a depender da matéria-prima e do trabalho empregado, além da raridade da obra e da notoriedade do artista. Já a categoria neofactual pode ser entendida como a descoberta de algum conteúdo acrescido à obra, que passa a ser percebida de maneira diferente pelo observador. Por fim, a categoria estética refere-se à fruição do observador com a obra, por meio dos sentidos.

A partir dessa análise, podemos apreciar e perceber o que nos provoca cada imagem artística ou mesmo o que nossa percepção nos permite desvelar em cada uma delas. Por isso, é importante que se permita um mergulho, um envolvimento esteticamente sensível, instigante, encantador, político e que se inicia com o olhar.

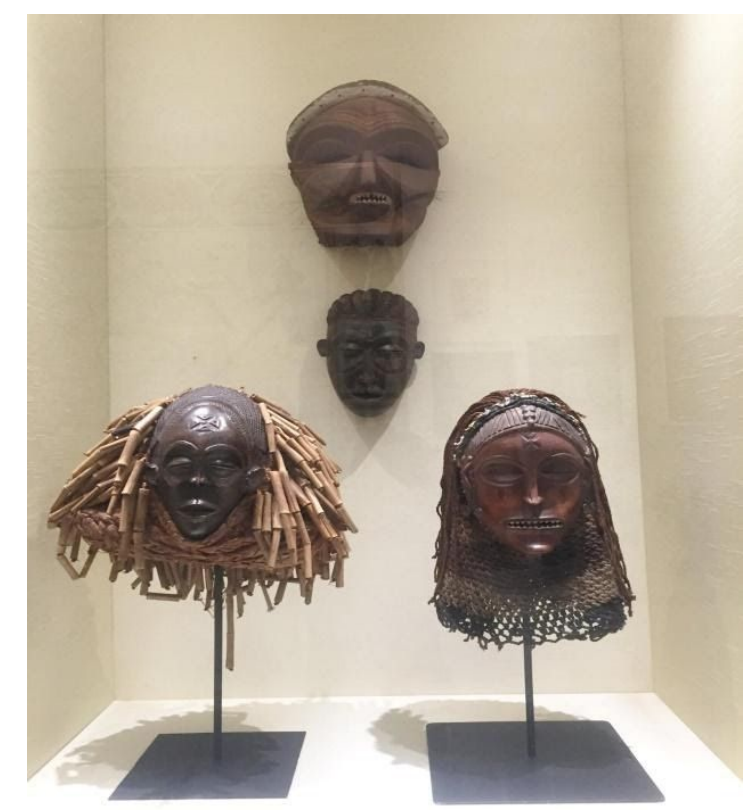

Figura 1 - Acervo do Museu AfroBrasil/SP. Fonte: a autora

$\mathrm{Na}$ Figura 1, entre outros aspectos, podemos perceber máscaras, rostos, cores, sombras, perspectiva, expressão, adornos. Que outras leituras podemos fazer? A que nos remete quando apreciamos essas obras? Que relações estabelecemos com elas? Que sentimentos, sensações, movimentos emergem 


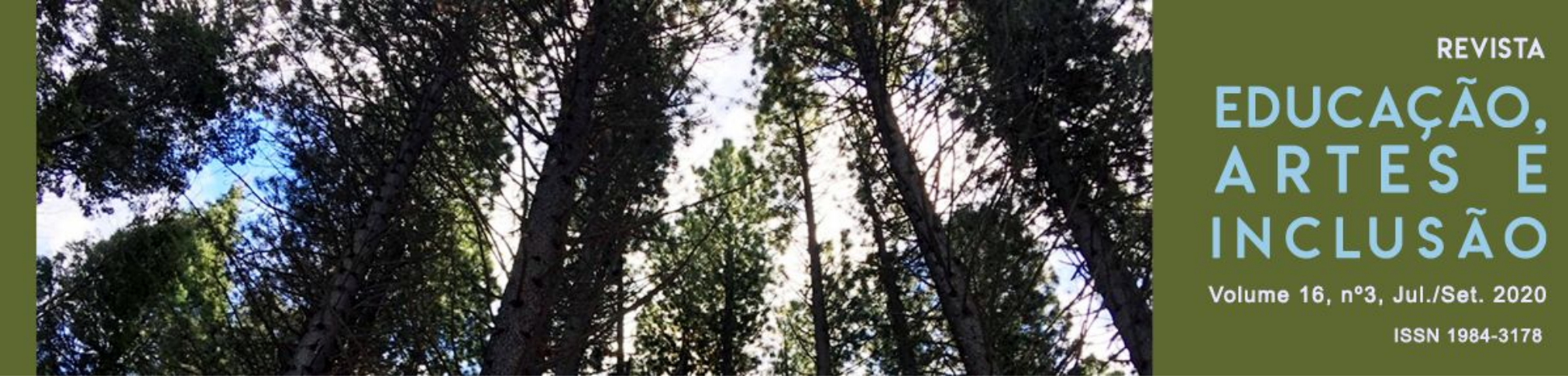

dessa relação? Esse é o exercício da apreciação; do espanto e da compreensão do fenômeno que, por vezes, poderia lhe parecer indiferente, invisível; porém, pode suscitar reflexões, desestabilizar preconceitos; possibilitar outros trânsitos na direção da diversidade, da pluralidade de cores, corpos, etnias, expressões de artes.

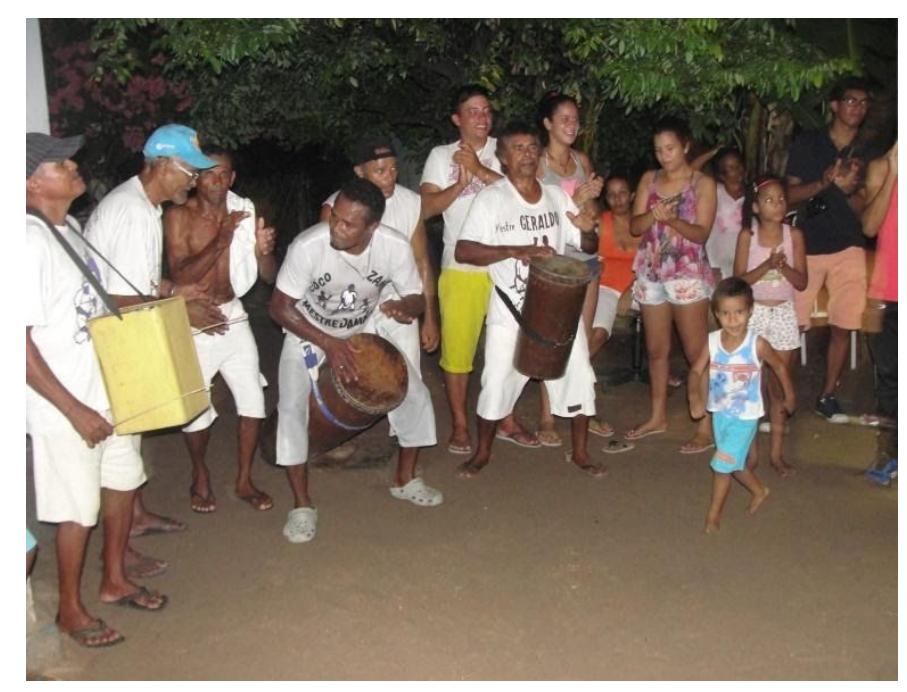

Figura 2 - Dança Coco de Zambê/Tibau do Sul/RN.

Fonte: a autora

Em relação à Figura 2, temos a imagem do Coco de Zambê, dança afro-brasileira presente na comunidade Cabeceiras, em Tibau do Sul, município do Rio Grande do Norte (ALVES, 2006). O que ela nos revela? O que nos transmite? Que aspectos emergem dessa cena? Quais outras questões podem ser desdobradas ao apreciarmos a presença de crianças, de adultos, de elementos simbólicos da cultura vivida por eles? Que aspectos de africanidades? 

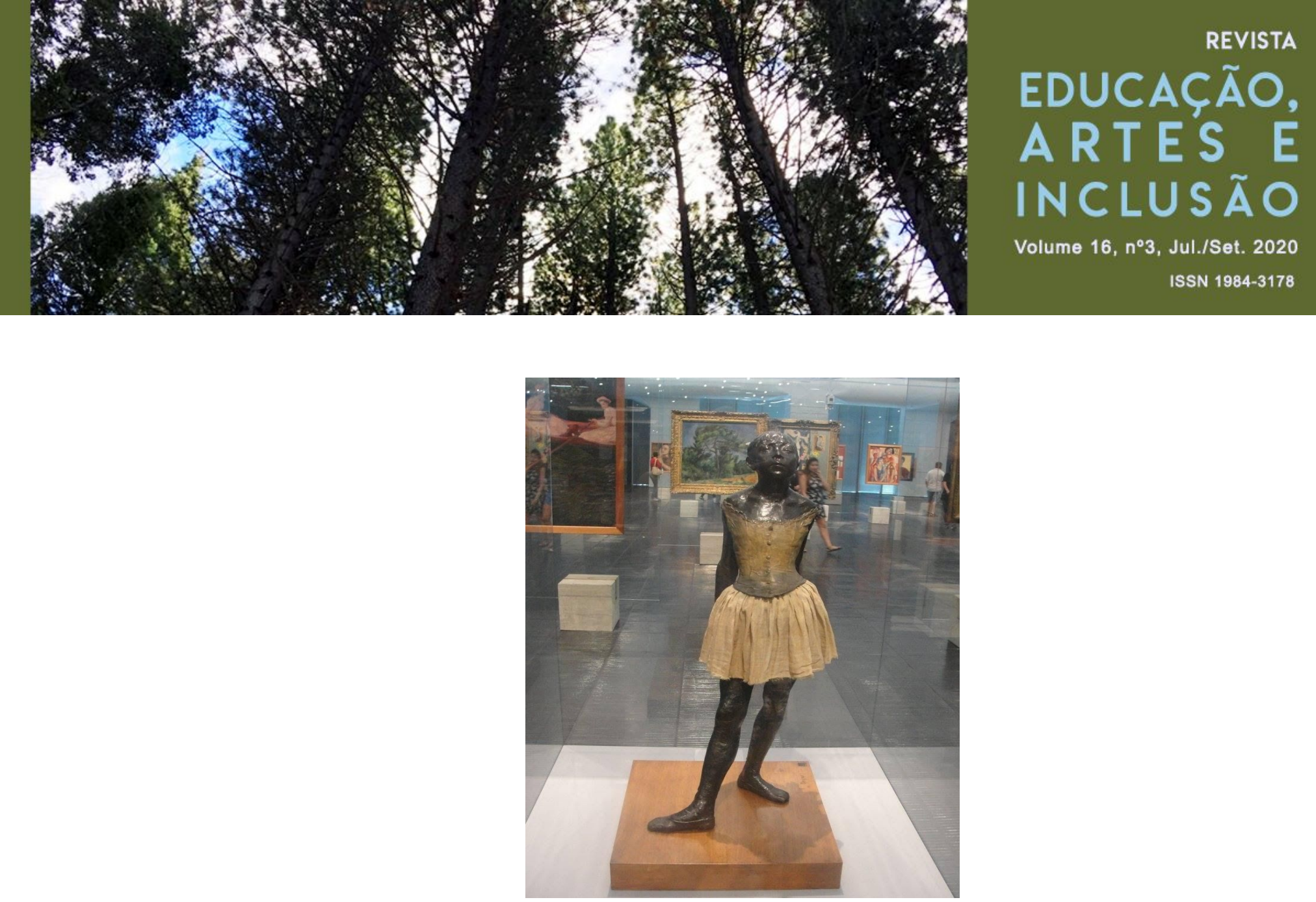

Figura 3 - Little Dancer, Ager Forteen, 1880. Edgar Degas — em MASP Fonte: a autora

Na Figura 3, temos uma bailarina que tende a nos provocar com seus gestos, sua cor, a posição de seus pés, a expressão de sua face e do corpo inteiro. O que ela nos fala? O que percebo e o que me provoca? Que questões são suscitadas a partir de uma figura que a priori poderíamos considerar como distante de um padrão europeu pré-estabelecido de uma bailarina? Que corpos dançam? 


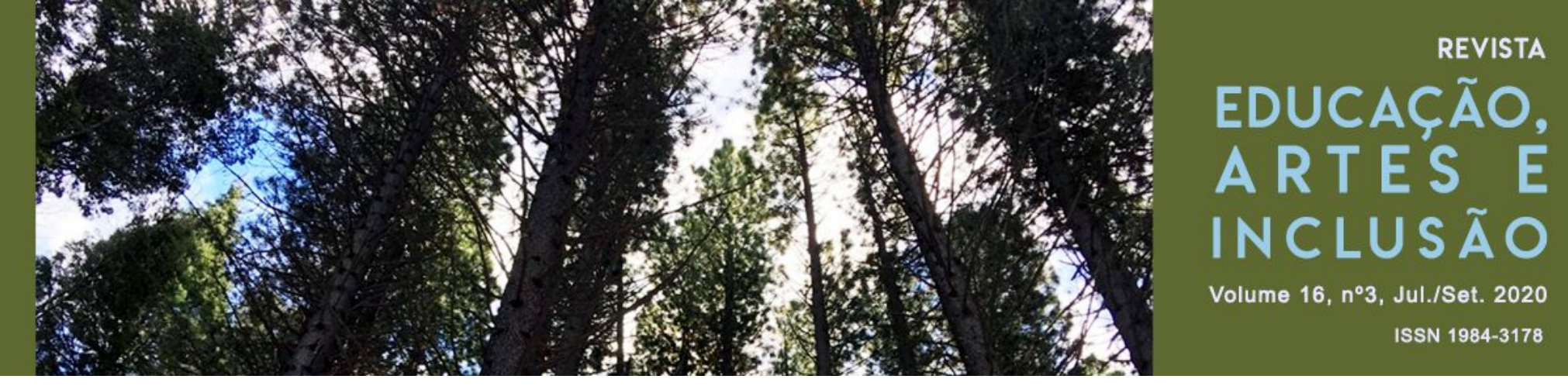

$\mathrm{Na}$ Figura 5, vemos as bonecas negras ocupando todo o espaço, o que nos diz? E uma boneca maior, seria uma contadora de histórias? Uma Griô? Uma guardiã de saberes e fazeres africanos? E o que suscita o olhar das crianças na fotografia atrás das bonecas? Onde estão as bonecas negras na nossa sociedade predominantemente eurocêntrica?

Sobre algumas das figuras supracitadas (particularmente 1, 4 e 5), é importante relacionarmos com o pensamento curatorial acerca do acervo do museu onde elas estão. A coordenadora de planejamento, Ana Lucia Lopes, destaca que:

A exposição do acervo do Museu Afro Brasil pretende contar uma outra história brasileira. [...] tem a intenção de desconstruir um imaginário da população negra, construído fundamentalmente pela ótica da inferioridade ao longo da nossa história e transformá-lo em um imaginário estabelecido no prestígio, na igualdade e no pertencimento, reafirmando assim o respeito por uma população matriz de nossa brasilidade (MUSEU AFRO BRASIL, 2015).

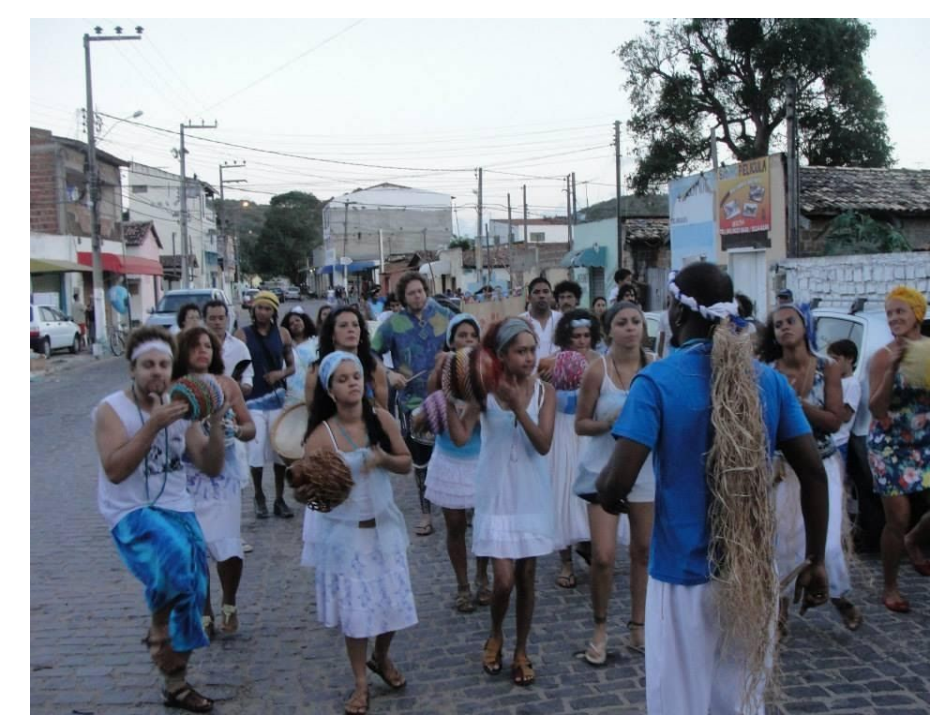

Figura 6 - Grupo Zamberacatu - participação no cortejo cultural da Vila de Ponta Negra, dentro do Projeto de extensão da UFRN Encantos da Vila.

Fonte: a autora

A Figura 6 nos desvela a rua ocupada por cultura, etnicidade negra, adornos, instrumentos, cânticos, cores, olhares, gente, ancestralidade. Trata-se do Grupo 


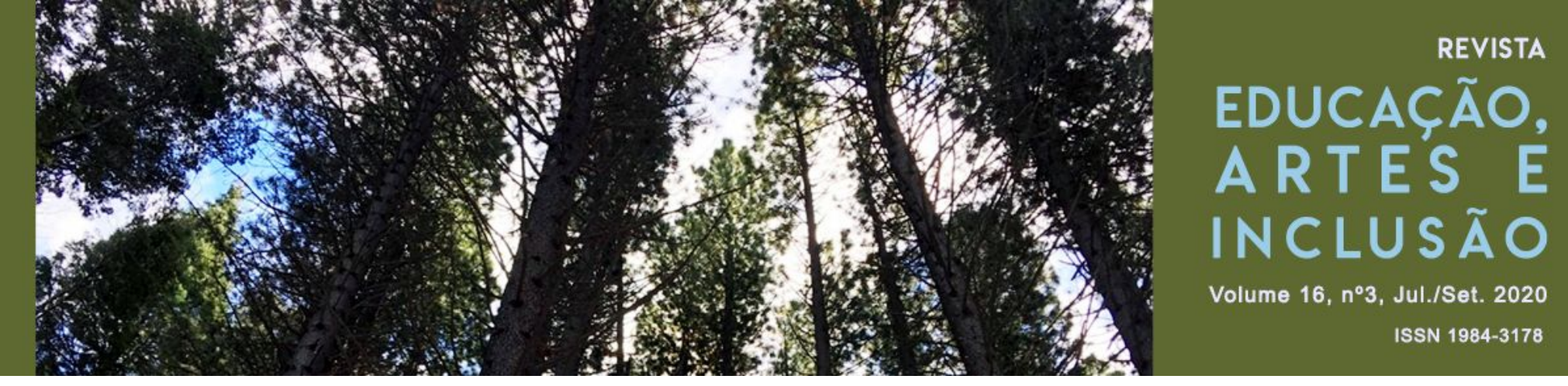

Nação Zamberacatú, nome inspirado na junção Coco de Zambê, anteriormente mencionado neste artigo, e o Maracatu. O grupo foi criado em 2012, como expressão de resistência da cultura negra no Rio Grande do Norte. Ao observarmos a imagem, em que nos afeta? Com o que nos identificamos? Respeitamos a cena, o fato, o movimento dos corpos que dançam, cantam, batucam, celebram e resistem?

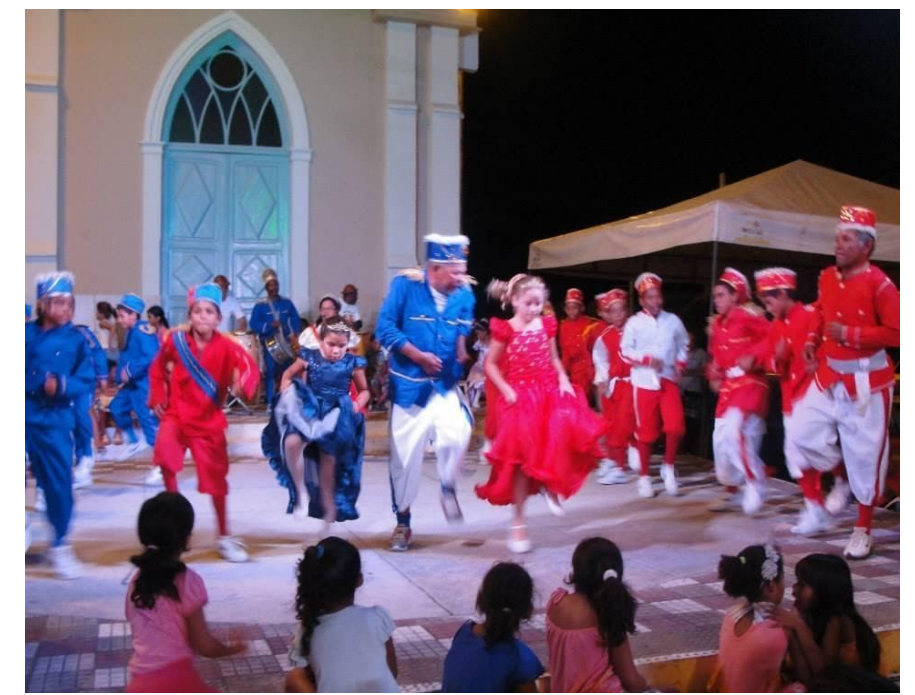

Figura 7 - Grupo Congos de Ponta Negra - participação no cortejo cultural da Vila de Ponta Negra, dentro do Projeto de extensão da UFRN Encantos da Vila.

Fonte: a autora

$\mathrm{Na}$ Figura 7, assistimos aos brincantes dos Congos sob os olhares atentos das crianças da comunidade. Trata-se do Grupo Congos de Calçola, manifestação secular da Vila de Ponta Negra, em Natal-RN (ALVES, 2010). Há cores, movimentos, adultos, crianças, cultura insistindo em permanecer, em continuar entoando suas embaixadas na luta pela terra e em respeito à memória de seus antepassados. Esse é um espaço sagrado para alguns, como a igreja; e para outros, por ser o território de sua dança, de seu grito e de lutas travadas a cada dia. O que mais nos desvela a imagem? O que conhecemos a respeito dessa e de outras manifestações similares? 

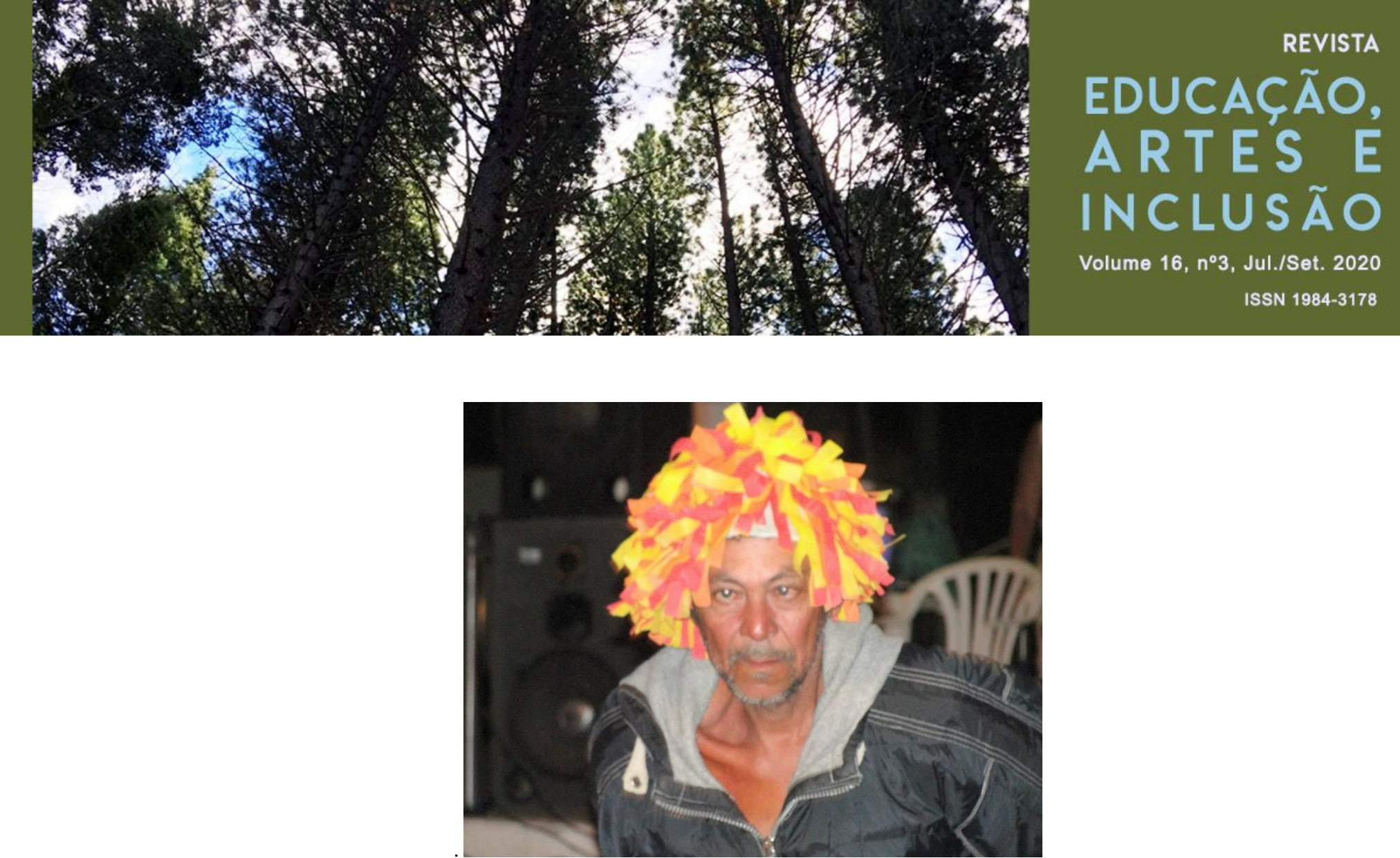

Figura 8 - Brincante-personagem Birico. Vila de Ponta Negra, Natal/RN Fonte: a autora

Para nós, a Figura 8 nos remete às memórias advindas dos encontros com o brincante Gari que assumia o personagem Birico no Grupo Boi Pintadinho da Vila de Ponta Negra. Como nos esquecer de seus pedidos de compra de pancake preto para pintar o seu rosto; de suas brincadeiras ao mexer com o público; de seu olhar fixo e em tom avermelhado encharcado pela bebida? Sua memória permanece; seus movimentos em evoluções sinuosas nas praças e ruas da Vila; sua incrível ludicidade e presença cênica de um exímio brincante popular jamais serão esquecidos por quem o conheceu e com ele brincou. Para o leitor ou leitora, o que mais pode ser percebido no encontro com essa imagem?

As imagens expostas nesta pesquisa, conforme anunciamos anteriormente, não se resumem a lançarmos questões e respostas sobre elas. Significam, sim, a possibilidade de provocar minimamente o olhar do observador na direção das nuances presentes em cada uma delas e na relação estabelecida com o próprio observador, sobretudo na perspectiva de promover fenomenologicamente um canal aberto para sentidos, sensações e sentimentos, como nos dizem Martins, Picosque e Guerra (1998), haja vista que a linguagem da arte fala e é lida por sua própria língua. Fica, portanto, o convite para novos olhares sobre essas mesmas imagens, 


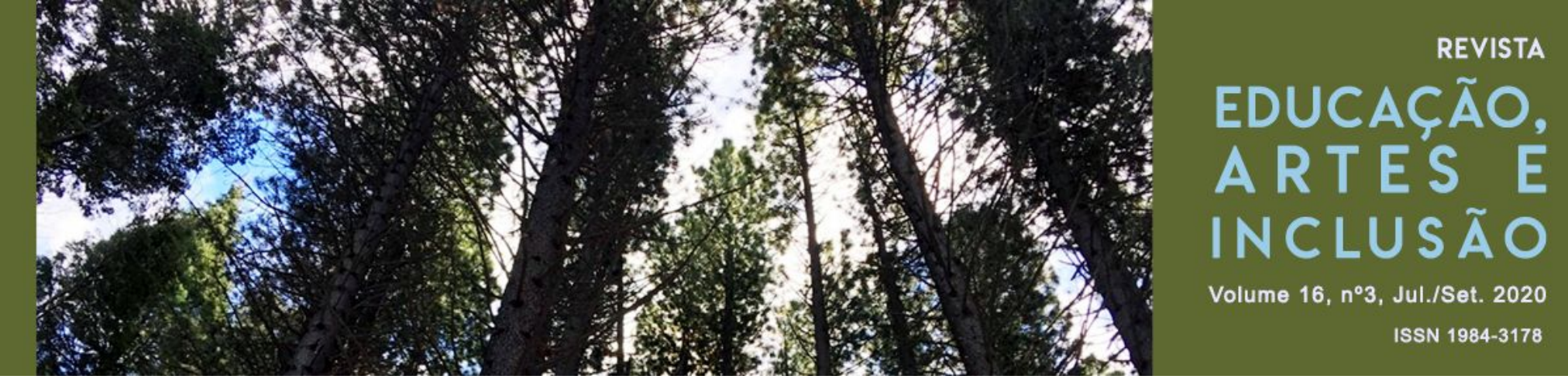

bem como a sugestão para que cada docente junto com seus estudantes, possam eleger outras tantas que digam respeito as suas realidades vividas; sejam imagens advindas dos diversos contextos artísticos ou mesmo de cenas cotidianas.

\section{CONSIDERAÇÕES E DESDOBRAMENTOS}

No intuito de desdobrarmos as reflexões registradas, imaginemo-nos em cada contexto vivido por essas pessoas, as das imagens e as que integram nossas aulas, considerando seus lugares, os elementos simbólicos presentes em suas expressões de arte, seus sentidos e significados. Essas imagens são exemplos do quão rico é esse universo étnico-cultural e, sobretudo, do que ele pode suscitar em cada um de nós, a ponto de reafirmamos identificações que nos afetam ou descontruirmos preconceitos, indiferenças que muitas vezes nos afastam dessa rica diversidade humana.

O corpo, por vezes, negado/oprimido em função da sua cor; da sua nacionalidade; da sua "classe social", da sua cultura, consegue resistir pela afirmação daquilo que coletivamente foi instituído como sendo sua identidade; seus processos identitários, sua africanidade. Nesse processo, a arte pode se tornar um elemento agregador de luta e afirmação.

Assim, a História dos corpos africanos, afro-brasileiros, é construída e incorporada por traços de submissão e resistência: de corpos escravizados como objetos; mas também de corpos-sujeitos expressivos, resistentes, conscientes da necessidade de lutar por igualdade de oportunidades em uma sociedade Ocidental ainda fortemente dualista, opressora e eurocêntrica. O presente artigo, portanto, traz essa reflexão como um chamamento a pensarmos sobre quais práticas institucionais temos adotado e validado no ensino superior, quando, por exemplo, fazemos escolhas por determinadas teorias, metodologias, assim como por autores e grupos. A esse respeito, é possível percebermos quão distante ainda está a presença de 


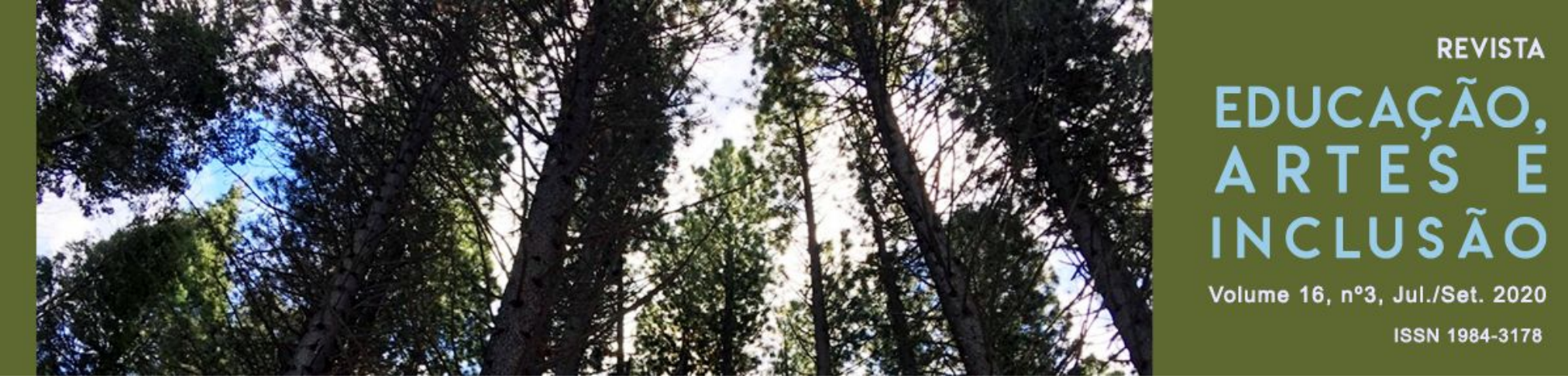

referências e práticas que se coadunem com a diversidade étnica e cultural que há hoje nesse ambiente acadêmico - esta tendo sido garantida, sobretudo, pela política de cotas para estudantes negros. Desse modo, ainda temos muito o que avançar, lançando um olhar sobre nós mesmos, como aprendizes de si, reconhecendo nossas limitações e potencialidades, bem como enxergando as vozes historicamente silenciadas. Conscientes dessa realidade, como docentes, acreditemos no nosso poder de mediação e continuemos fortalecendo as lutas por uma educação superior realmente pluriversitária e decolonial, respeitando os diversos corpos sujeitos e considerando suas referências étnicas e culturais.

\section{REFERÊNCIAS}

ALVES, T. de A. Aprendendo com o Coco de Zambê: aquecendo a educação com a ludicidade, a corporeidade e a cultura popular. Dissertação (Mestrado em Educação) Universidade Federal do Rio Grande do Norte, Natal, 2000.

Encantos da vila, vivenciando saberes: uma experiência com arte, cultura e educação. Natal: EDUFRN, 2010.

Herdanças de corpos brincantes: saberes da corporeidade em danças afro-brasileiras. Natal: EDUFRN, 2006.

ANDRADE, Mario de. 0 turista aprendiz. Brasília: IPHAN, 2015.

BÂ, Hampaté A. A educação tradicional na África. Revista Palas Athena, n. 64, 1997.

BOFF, Leonardo. A voz do arco-íris. Brasília: Letraviva, 2000.

BRANDÃO, Ana Paula (coord.). Saberes e Fazeres: modos de sentir. v. 2. Rio de Janeiro: Fundação Roberto Marinho, 2006. (A cor da cultura).

BRASIL. Lei $\mathbf{n}^{\circ} \mathbf{1 0 . 6 3 9}$, de 09 de janeiro de 2003. Altera a Lei no 9.394, de 20 de dezembro de 1996, que estabelece as diretrizes e bases da educação nacional, para incluir no currículo oficial da Rede de Ensino a obrigatoriedade da temática "História e Cultura Afro-Brasileira", e dá outras providências. Disponível em:

http://www.planalto.gov.br/ccivil_03/leis/2003/l10.639.htm. Acesso em: 26 maio 2020. 


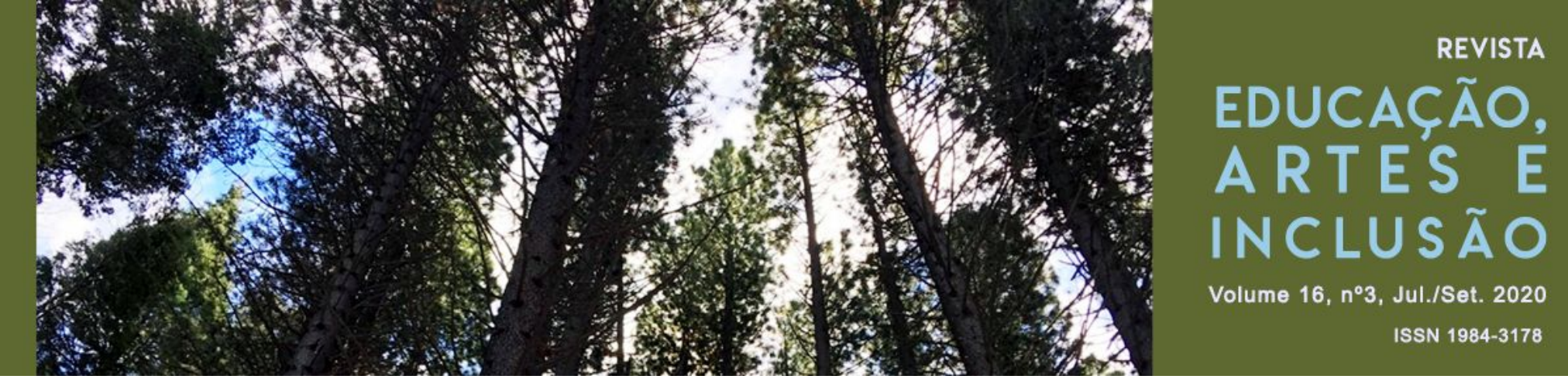

BRASIL. Lei $\mathbf{n}^{\circ} \mathbf{1 1 . 6 4 5}$, de 10 de março de 2008. Altera a Lei no 9.394, de 20 de dezembro de 1996, modificada pela Lei no 10.639, de 9 de janeiro de 2003, que estabelece as diretrizes e bases da educação nacional, para incluir no currículo oficial da rede de ensino a obrigatoriedade da temática "História e Cultura Afro-Brasileira e Indígena". Disponível em: http://www.planalto.gov.br/ccivil_03/_Ato2007-2010/2008/Lei/L11645.htm. Acesso em: 26 maio 2020.

CATEL, Gisele; SAVINO, Wilson. O corpo na arte africana. Rio de Janeiro: Museu da Vida; Casa de Oswaldo Cruz; FIOCRUZ, 2012.

COSTELLA, Antônio F. Para apreciar a arte: roteiro didático. São Paulo: SENAC, 1997.

FREIRE, Paulo. Cartas à Guiné-Bissau. Registros de uma experiência em processo. Rio de Janeiro: Paz e Terra, 1978.

INOCÊNCIO, Nelson. Navios negreiros como lugares de memória na arte afrocontemporânea. In: PASSOS, Mailsa C. P.; PEREIRA, Rita Marisa R. Educação experiência estética. Rio de Janeiro: Nau Editora, 2011.

LE BRETON, David. O corpo tornou-se um simples acessório. O Estado de S. Paulo, 7 fev. 2008. (Reportagem e entrevista concedida a Flávia Tavares).

MARTINS, Mirian C.; PICOSQUE, Gisa. Mediação cultural para professores andarilhos na cultura. São Paulo: Intermeios, 2012.

MARTINS, Mirian C.; PICOSQUE, Gisa; GUERRA, M. Terezinha. Didática do ensino de arte: a língua do mundo: poetizar, fluir e conhecer arte. São Paulo: FTD, 1998.

MERLEAU-PONTY, Maurice. Fenomenologia da percepção. São Paulo: Martins Fontes, 1999.

MIGNOLO, Walter D. Colonialidade: o lado mais escuro da modernidade. Rev. bras. Ci. Soc., São Paulo, v. 32, n. 94, 2017. Disponível em: http://dx.doi.org/10.17666/329402/2017. Acesso em: 10 set. 2019.

MUNANGA, Kabenguele. Programa salto para o futuro (entrevista). Brasília: TVE Brasil, 11 set. 2008.

MUNANGA, Kabenguele. Entrevista concedida ao Programa Salto para o Futuro/ TV Escola, em 11/9/2008.

MUSEU AFRO BRASIL. O acervo Museu Afro Brasil. São Paulo, 2015. Disponível em: http://www.museuafrobrasil.org.br/noticias/detalhe-noticia/2015/09/30/o-acervo-museu-afro-b rasil. Acesso em: 2 abr. 2020. 


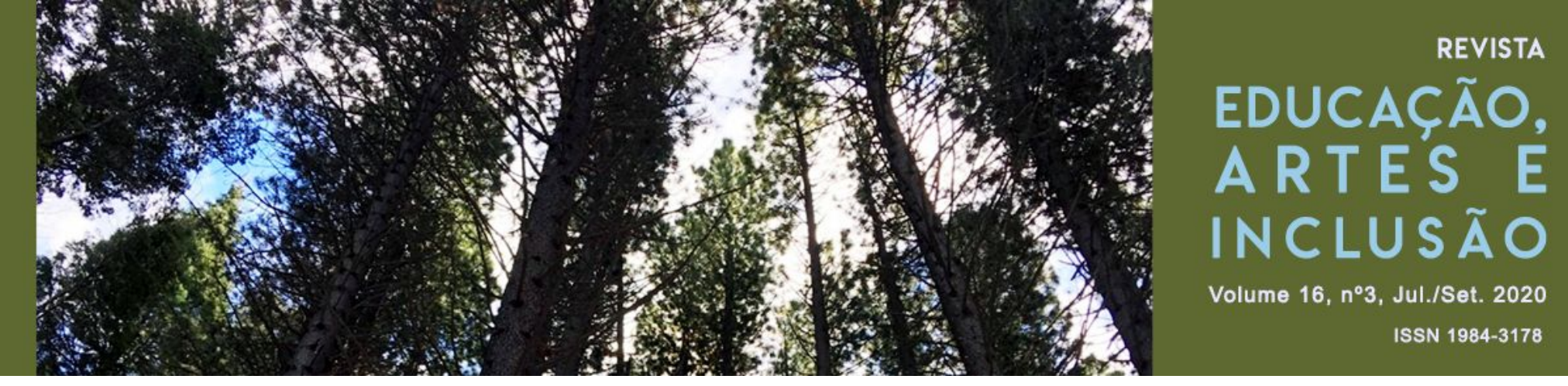

PORTO-GONÇALVES, Carlos Walter. Apresentação da edição em português. In: LANDER, Edgardo (org.). A colonialidade do saber: eurocentrismo e ciências sociais. Perspectivas latino-americanas. Ciudad Autónoma de Buenos Aires: CLACSO, 2005. p. 9-15. (Colección Sur Sur). Disponível em:

http://bibliotecavirtual.clacso.org.ar/ar/libros/lander/pt/ApreemPort.rtf. Acesso em: 10 set. 2019.

QUERINO, Manuel. Costumes africanos no Brasil. 2. ed. Recife: FUNDAJ/Editora Massangana/FUNARTE, 1988.

SANTOS, Boaventura de Sousa; MENESES, Maria Paula (org.). Epistemologias do Sul. São Paulo: Cortez, 2010.

SENGHOR, Léopold Sédar. El espíritu de la civilización, o las leyes de la cultura africana negra. In: KOHN, Hans; SOKOLSKY, Wallace. El nacionalismo africano em el siglo XX. Buenos Aires: Editorial Paidos, 1968. p. 191-208.

SIQUEIRA, Maria de L. Conhecimento, consciência e memória cultural africana no Brasil. In: ENCONTRO DE PESQUISA EDUCACIONAL DO NORTE NORDESTE -EPENN, 15., 2001, São Luís. Anais [...]. São Luís: [s.n.], 2001. 